\title{
Effect of stocking densities of grey mulle (Mugil cephalus) reared on natural food in monoculture earthen ponds on growth performance and total production with economical evaluation
}

\author{
Ahmed S. Abdel-Gawad ${ }^{1}$; Abdel-Rahman A.Salama ${ }^{2}$. \\ 1-Fish Biology and Ecology dept., Central Laboratory for Aquaculture \\ Research, Agricultural Research Center, Egypt. \\ 2-Fish Economy dept., Central Laboratory for Aquaculture Research, \\ Agricultural Research Center, Egypt
}

\begin{abstract}

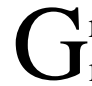
rowth performance, total fish yield and economical evaluation of the grey J mullet Mugil cephalus (L.) at different stocking densities were compared in monoculture system without any supplementary feeding. Four stocking densities at rate of 1050, 1400, 2100 and 4200 fish/feddan (0.42 ha) for treatments, $\mathrm{T}_{1}, \mathrm{~T}_{2}$, $\mathrm{T}_{3}$ and $\mathrm{T}_{4}$ respectively, were carried out in eight freshwater earthen ponds. Ponds were fertilized with organic and inorganic fertilizers, $(60 \mathrm{~kg}$; chicken manure, 30 kg. super phosphate and 10.0kg urea per feddan biweekly). Results indicated that the main individual growth rate was highest for lower density and lowest for the higher density. Final body weight was 231.86, 182.82, 151.19 and $91.65 \mathrm{~g}$ /fish for $\mathrm{T}_{1}, \mathrm{~T}_{2}, \mathrm{~T}_{3}$ and $\mathrm{T}_{4}$ respectively, with significant difference $(\mathrm{p}<0.05)$.

Final body length, SGR (\%), RGR (\%), daily weight gain, survival rate, condition factor, economic evaluation and sensitivity analysis were discussed. Total fish production values at the end of experimental period (180 days) were 233.7, 236.8, 273.0 and $313.9 \mathrm{~kg}$. / feddan (0.42 ha.) for $\mathrm{T}_{1}, \mathrm{~T}_{2}, \mathrm{~T}_{3}$ and $\mathrm{T}_{4}$ respectively.

It could be concluded that treatment $\left(\mathrm{T}_{1}\right)$ that received the lowest stocking density at the rate of 1050 grey mullet Mugil cephalus fingerlings per feddan (0.42 ha.), without any supplementary food, and cultured for 180 days in monoculture system, had the highest net return and rate of return, followed by $\mathrm{T}_{2}$ and $T_{3}$, which can reduce the risk for the farmer in the event of unexpected fall in market price or production or increasing of costs.
\end{abstract}

Key words: Monoculture, grey mullet, Mugil cephalus, growth performance, earthen ponds, total production, economic evaluation and sensitivity analysis.

\section{INTRODUCTION}

Mullet are an extremely important fish which are cultured in many countries, particularly in the Mediterranean (Smith and Swart, 1998). They feed at the lowest trophic levels on plant detritus and algae (Oren, 1981). 
Striped grey mullet is long considered to feed primarily on detritus, however recent researches has indicated that they obtain much of their food from plankton, (Cardona, et al; 1996).

Mullet are well suited for farming since they feed on algae, diatoms, small crustaceans, decayed organic matter and mud; hence there is a little need to feed (Swart, et al; 2001). Also, they were mainly detritivorous and shifted to zooplankton (Blanco, 2003).

Mugil cephalus is one of the most important mullet species for culture purposes. This due to high quality flesh, superior growth, large maximum size and wide salinity and temperature tolerance, (Smith and Swart, 1998).

As known, fertilization and supplementary feeding led to best growth rate of M.cephalus compared to supplementary feeding only (Abd-El-Tawab and Yones, 2001). It means that striped mullet could utilize both supplemental and / or natural food, (Abdel-Tawwab et al, 2005). But, the availability of natural feed increased the growth of $M$. cephalus by $20.7 \%$ in absence of supplementary preferable feeding (Essa, et al, 1989).

The fry Liza ramada, L. aurata, L. saliens, Chelon labrosus and Mugil cepahlus in a lagoon in NE Spain fed mainly on zooplanktonic crustacean, such as cyclopaids, clnoids and cladocerans, but adult chironomids were also important. (Gisbert, et al., 1995).

Flathead grey mullet enhanced phytoplankton development due to the removal of large cladocerans and not as consequence of nutrient release. Furthermore, they strongly modified the benthic community, probably due to direct predation, (Torras et al., 2000).

Jana et al; (2004) reported that a periphyton-supported aquaculture system can be used successfully for the culture of herbivorous brackish water fish species like Mugill cephalus in inland saline ground waters and thus could contribute to the development of sound and sustainable aquaculture technology.

Grey mullet obtain food from the benthos and plankton and they dramatically affect plankton and benthos composition. So, in the presence of grey mullet, rotifers density was low, cladocerance were completely absent and small phytoplankton were very dense (Cardona, et al., 1996).

Grey mullet could be cultivated in monoculture system or poly-culture system. So, it was found that when the striped mullet reared in monoculture and in lower density, they had greater growth and weight gain (Scorvo et al., 1995).

Eid, (2006) found that the optimum stocking density of grey mullet $M$. cephalus is about 10000 fish /feddan (0.42 ha.) in fertilized brackish water ponds with artificial feeding. But, Bakeer (2006) reported that the best stocking rate of grey mullet Mugill cephalus fingerlings during rearing period 32 weeks in brackish water ponds was 2 fish $/ \mathrm{m}^{3}$ under fertilization and artificial feeding.

In polyculture system, Oreochromis niloticus was stocked with Mugil cephalus at stocking density of 8000 fish / fed. (0.42 ha.), at different ratio (60:40, 70:30, 80:20 and 90:10). The best mixed species ratio was $70 \%$ of 
O.niloticus and $30 \%$ of $\mathrm{M}$. cephalus for highest pond production in polyculture system (Abdel-Gawad, 2003).

In mixed cultivation of mullet Mugil Liza and white shrimp Litopenaus schmitti, the low density of mullet in ponds did not affect the main variables in the cultivation of shrimp contributing to improve economic and productive indicators (Artiles, et al., 2001).

Magouz, et al ;(1999), reported that economic efficiency was superior in ponds fertilized with (10 kg urea $+25 \mathrm{~kg}$ MSP biweekly) for grey mullet $M$. cephalus cultivated in polyculture system with red tilapia.

Soliman, et al; (2000) found that the rearing of grey mullet $M$. cephalus in polyculture ponds with common carp, silver carp and tilapias in both of integrated and non-integrated systems, the data on return on sales, return on costs, return on equity pay-back period and break-even point showed that the integrated system was more profitable than non-integrated system.

Eid, (2006) cited that the stocking density 10000 fish /feddan (0.42 ha.), of grey mullet $M$. cephalus in monoculture with supplementary feeding, seemed to economic thus applied when it increased net production followed by stocking density $12000 \mathrm{fish} /$ feddan, and stocking density $14000 \mathrm{fish} / \mathrm{feddan}$.

Bakeer, (2006) reported that in grey mullet $M$. cephalus monoculture system, with supplementary feeding, the highest profitability was recorded for the lowest stocking density which had the rate of $1 \mathrm{fish} / \mathrm{m}^{3}$.

The present study aimed to investigate the different stocking densities of grey mullet Mugil cephalus reared in earthen ponds without any supplementary feeding, and their effects on growth performance, total final yield, and economical potential, also, to evaluate the sensitivity analysis for different stocking densities estimating the risk to save the farmer in the case of applying the result of this study.

\section{MATERIALS AND METHODS}

This work was conducted in Central Laboratory for Aquaculture Research (CLAR) at Abbassa, Abo-Hammad, Sharkia governorate, Egypt. Eight earthen ponds 0.1 ha. (each) with one meter water depth, were used. Ponds were supplied by gravity with fresh water from Ismailia canal. The experiment was run during summer 2004 for 180 days (from 7 May to 3 November).

Ponds were fertilized with organic and chemical fertilizers at the rate of 60 $\mathrm{kg}$, chicken manure, $30 \mathrm{~kg}$ mono-super phosphate $\mathrm{Ca}\left(\mathrm{H}_{2} \mathrm{PO}_{4}\right)_{2}$ and $10 \mathrm{~kg}$; urea $(46.5 \% \mathrm{~N})$ per feddan (0.42 ha) biweekly to accelerate phytoplankton and zooplankton (Magouz,et al;1999 and Abdel-Gawad, 2003). The fertilization was started one week before fish stocking and stopped tow weeks before fish harvesting.

Ponds were stocked in monoculture system with grey mullet Mugil cephalus fingerlings at four densities. The rate of densities was1050, 1400, 2100 
and 4200 fish / feddan (0.42 ha) for treatments $T_{1}, T_{2}, T_{3}$ and $T_{4}$ respectively. Each treatment was replicated at the same conditions.

Initial body weight of grey mullet fingerlings was $12.10 \pm 0.07 \mathrm{~g} /$ fish and initial body length of $6.51 \pm 0.05 \mathrm{~cm} /$ fish for all treatments.

Water sample were taken daily in the early morning and the physical properties, temperature, oxygen, $\mathrm{pH}$ and (secchi disk) of pond water determine according to (APHA,. 1985), and the measuring of water parameter values were represented in Table (1).

Table (1) Average of physical and chemical properties of pond water during experimental period (180days) through intervals (30 days) (mean $\pm \mathrm{SE}$ )*

\begin{tabular}{|c|c|c|c|c|c|c|c|}
\hline \multirow[b]{2}{*}{ Items } & \multicolumn{4}{|c|}{ Intervals } & & & \\
\hline & Initial & $\begin{array}{c}\text { After } 30 \\
\text { days }\end{array}$ & $\begin{array}{c}\text { After } \\
\text { 60days }\end{array}$ & $\begin{array}{c}\text { After } \\
\text { 90days }\end{array}$ & $\begin{array}{c}\text { After } \\
\text { 120days }\end{array}$ & $\begin{array}{c}\text { After } \\
\text { 150days }\end{array}$ & $\begin{array}{c}\text { After } \\
\text { 180days }\end{array}$ \\
\hline Temperature $\left(\mathrm{C}^{0}\right)$ & $\begin{array}{l}25.8 \\
\pm 0.4\end{array}$ & $\begin{array}{r}27.3 \\
\pm 0.45\end{array}$ & $\begin{array}{l}28.4 \\
\pm 0.5\end{array}$ & $\begin{array}{l}29.8 \\
\pm 0.3\end{array}$ & $\begin{array}{r}28.9 \\
\pm 0.31\end{array}$ & $\begin{array}{c}26.1 \\
\pm 0.02\end{array}$ & $\begin{array}{r}24.4 \\
\pm 0.15\end{array}$ \\
\hline $\begin{array}{l}\text { Seccki Disk } \\
(\mathrm{cm})\end{array}$ & $\begin{array}{c}15.5 \\
\pm 0.28\end{array}$ & $\begin{array}{l}15.3 \\
\pm 0.3\end{array}$ & $\begin{array}{l}15.2 \\
\pm 0.4\end{array}$ & $\begin{array}{r}14.9 \\
\pm 0.35\end{array}$ & $\begin{array}{c}14.7 \\
\pm 0.23\end{array}$ & $\begin{array}{r}14.3 \\
\pm 0.21\end{array}$ & $\begin{array}{l}13.9 \\
\pm 0.35\end{array}$ \\
\hline $\begin{array}{l}\text { PH values } \\
\text { Unit) }\end{array}$ & $\begin{array}{r}8.3 \\
\pm 0.1\end{array}$ & $\begin{array}{c}8.4 \\
\pm 0.11\end{array}$ & $\begin{array}{c}8.9 \\
\pm 0.15\end{array}$ & $\begin{array}{c}8.7 \\
\pm 0.2\end{array}$ & $\begin{array}{c}9.0 \\
\pm 0.14\end{array}$ & $\begin{array}{c}9.2 \\
\pm 0.09\end{array}$ & $\begin{array}{c}9.1 \\
\pm 0.08\end{array}$ \\
\hline $\begin{array}{l}\text { D. Oxygen } \\
(\mathrm{mg} / \mathrm{L})\end{array}$ & $\begin{array}{r}5.8 \\
\pm 0.2\end{array}$ & $\begin{array}{c}5.7 \\
\pm 0.25\end{array}$ & $\begin{array}{c}5.3 \\
\pm 0.27\end{array}$ & $\begin{array}{c}4.8 \\
\pm 0.35\end{array}$ & $\begin{array}{c}4.6 \\
\pm 0.32\end{array}$ & $\begin{array}{r}4.3 \\
\pm 0.4\end{array}$ & $\begin{array}{c}4.9 \\
\pm 0.38\end{array}$ \\
\hline Hardness (mg/L) & $\begin{array}{l}240 \\
\pm 4.4\end{array}$ & $\begin{array}{r}220 \\
\pm 7.8\end{array}$ & $\begin{array}{r}545 \\
\pm 8.6\end{array}$ & $\begin{array}{r}590 \\
\pm 66\end{array}$ & $\begin{array}{r}470 \\
\pm 8.2\end{array}$ & $\begin{array}{r}350 \\
\pm 5.8\end{array}$ & $\begin{array}{r}275 \\
\pm 6.3\end{array}$ \\
\hline Alkalinity (mg/l) & $\begin{array}{r}263 \\
\pm 35\end{array}$ & $\begin{array}{r}270 \\
\pm 25\end{array}$ & $\begin{array}{r}250 \\
\pm 35\end{array}$ & $\begin{array}{r}220 \\
\pm 15\end{array}$ & $\begin{array}{l}300 \\
\pm 40\end{array}$ & $\begin{array}{r}370 \\
\pm 25\end{array}$ & $\begin{array}{l}170 \\
\pm 30\end{array}$ \\
\hline NO3 (mg/L) & $\begin{array}{r}0.28 \\
\pm 0.03\end{array}$ & $\begin{array}{r}0.27 \\
\pm 0.05\end{array}$ & $\begin{array}{r}0.50 \\
\pm 0.04\end{array}$ & $\begin{array}{c}0.67 \\
\pm 0.06\end{array}$ & $\begin{array}{r}0.61 \\
\pm 0.04\end{array}$ & $\begin{array}{r}0.52 \\
\pm 0.03\end{array}$ & $\begin{array}{r}0.34 \\
\pm 0.02\end{array}$ \\
\hline
\end{tabular}

The time of dissolved oxygen test is 9:00

The chemical properties (total hardness and total alkalinity) of ponds water also determined according to (Boyd, 1992), every two weeks through the entire experimental period. 
Live body weight and total length of random samples of (100-400 fish/feddan according to the rate of density) were taken monthly. The fish were netted from the water of pond, weighed to the nearest gram and length was measured to nearest $1 \mathrm{~mm}$. At the end of experimental period, ponds were drained from the water and the fish were harvested by seining. Total fish production for each treatment was weighed and graduated.

Parameters of relative growth rate (RGR \%), specific growth rate (SGR \%), daily weight gains (DWG) and condition factor (K), was calculated according to the following equation:

* Daily weight gain (DWG) was calculated as: $\left(\mathrm{W}_{2}-\mathrm{W}_{1}\right) / \mathrm{t}$, where $\mathrm{W}_{2}$ is the interval time in days.

*Total gain g / fish: Average of final weight (g) - Average of initial fish weight (g).

* Condition factor $(\mathrm{K})=$ weight $(\mathrm{g}) /(\text { length } \mathrm{cm})^{3} .100$

* Relative growth rate (RGR \%) was calculated as: $\left(\mathrm{W}_{2}-\mathrm{W}_{1} / \mathrm{W}_{1}\right)-100$

*Specific growth rate (SGR \%) was calculated as: $\left(\mathrm{Ln} \mathrm{W}_{2}-\mathrm{Ln} \mathrm{W}_{1} / \mathrm{t}\right) .100$.

Economical evaluation:-

The evaluation of economic potential and profitability of an enterprise, estimated costs and returns associated with the enterprise are calculated (Shang, 1981).

No charge for land was included in the cost estimates, land was assumed to be owned and previously used for aquaculture.

\section{Statistical Analysis:}

All statistical evaluations were run using the programs (SAS, 1987). Deference among means was tested at 5\% probability level using Duncan's new multiple ranges test (Duncan, 1955).

\section{RESULTS AND DISCUSSION}

\section{Body weight (W) and body length (L):}

Average body weight and average body length of grey mullet Mugil cephalus during experimental period intervals (one interval $=30$ days) are represented in Table (2).The average of initial body weight was $12.1 \pm 0.07 \mathrm{~g}$ /fish with insignificant differences $(\mathrm{p}<0.05)$. This indicates that all used $M$. cephalus fingerlings were of the same weight.

Results of Table (2) revealed that the different stocking density released significant effects on grey mullet $M$. cephalus body weight during the experiment period. The difference among groups in body weight were significant $(\mathrm{P}<0.05)$.That can be noticed at the first interval (after 30 days of the experiment started); the body weight was 31.46, 27.11, 24.83 and $19.35 \mathrm{~g} /$ fish for $\mathrm{T}_{1}, \mathrm{~T}_{2}, \mathrm{~T}_{3}$ and $\mathrm{T}_{4}$ respectively. The same 
trend can be observed at all intervals. The final body weight was 231.86 $\pm 0.58,182.82 \pm 0.37,151.19 \pm 0.44$ and $91.65 \pm 0.47 \mathrm{~g} /$ fish for $\mathrm{T}_{1}, \mathrm{~T}_{2}$, $\mathrm{T}_{3}$ and $\mathrm{T}_{4}$ respectively. These results indicate that final body weight of M.cephalus increased significantly $(\mathrm{p}<0.05)$ with the decreasing of stocking density. The results are in agreement with those reported by (Abdel-Hakim, et al; 2006; Bakeer, 2006; and Eid, 2006) who found that the growth of grey mullet was influenced by the different stocking density fertilization and supplementary feeding.

Table (2) Average of body weight (W) in g/fish and body length (L) in $\mathrm{cm} /$ fish of $M$. cephalus during experimental period through intervals (30 days) (mean \pm SE)* at culture period 180 days.

\begin{tabular}{|c|c|c|c|c|c|c|c|c|}
\hline \multirow[t]{2}{*}{ Intervals } & \multicolumn{4}{|c|}{ Average body Weight (W) g } & \multicolumn{4}{|c|}{ Average of Body Length (L) cm } \\
\hline & T1 & $\mathrm{T} 2$ & T3 & T4 & T1 & $\mathrm{T} 2$ & T3 & T4 \\
\hline Initial & $\begin{array}{l}12.10 \mathrm{a} \\
\pm 0.07\end{array}$ & $\begin{array}{l}12.10 \mathrm{a} \\
\pm 0.07\end{array}$ & $\begin{array}{c}12.10 \quad \mathrm{a} \\
\pm 0.07\end{array}$ & $\begin{array}{c}12.10 \quad \mathrm{a} \\
\pm 0.07\end{array}$ & $\begin{array}{c}6.51 \quad \mathrm{a} \\
\pm 0.05\end{array}$ & $\begin{array}{l}6.51 \quad \text { a } \\
\pm 0.05\end{array}$ & $\begin{array}{l}6.51 \quad \text { a } \\
\pm 0.05\end{array}$ & $\begin{array}{l}6.51 \quad \mathrm{a} \\
\pm 0.05\end{array}$ \\
\hline $\begin{array}{c}\text { After } 30 \\
\text { days }\end{array}$ & $\begin{array}{c}31.46 \mathrm{a} \\
\pm 0.18\end{array}$ & $\begin{array}{c}27.11 \mathrm{~b} \\
\pm 0.26\end{array}$ & $\begin{array}{l}24.83 \text { с } \\
\pm 0.18\end{array}$ & $\begin{array}{c}19.35 \mathrm{~d} \\
\pm 0.11\end{array}$ & $\begin{array}{c}9.42 \quad \mathrm{a} \\
\pm 0.10\end{array}$ & $\begin{array}{l}9.08 \quad \mathrm{~b} \\
\pm 0.11\end{array}$ & $\begin{array}{c}9.02 \quad b \\
\pm 0.11\end{array}$ & $\begin{array}{l}8.50 \mathrm{c} \\
\pm 0.15\end{array}$ \\
\hline $\begin{array}{c}\text { After } 60 \\
\text { days }\end{array}$ & $\begin{array}{c}60.22 \mathrm{a} \\
\pm 0.21\end{array}$ & $\begin{array}{c}49.19 \mathrm{~b} \\
\pm .26\end{array}$ & $\begin{array}{c}43.51 \quad \text { с } \\
\pm 0.41\end{array}$ & $\begin{array}{c}30.42 \mathrm{~d} \\
\pm 0.29\end{array}$ & $\begin{array}{c}12.69 \text { a } \\
\pm 0.104\end{array}$ & $\begin{array}{c}11.7 \mathrm{ab} \\
\pm 0.20\end{array}$ & $\begin{array}{c}11.52 \mathrm{~b} \\
\pm 0.15\end{array}$ & $\begin{array}{c}10.47 \text { c } \\
\pm 0.1\end{array}$ \\
\hline $\begin{array}{c}\text { After } 90 \\
\text { days }\end{array}$ & $\begin{array}{c}95.80 \text { a } \\
\pm 0.19\end{array}$ & $\begin{array}{c}77.14 \mathrm{~b} \\
\pm 0.27\end{array}$ & $\begin{array}{c}66.52 \quad \mathrm{c} \\
\pm 0.24\end{array}$ & $\begin{array}{c}43.74 \mathrm{~d} \\
\pm 0.34\end{array}$ & $\begin{array}{c}14.69 \text { a } \\
\pm 0.17\end{array}$ & $\begin{array}{c}14.07 \mathrm{~b} \\
\pm 0.18\end{array}$ & $\begin{array}{c}13.87 \mathrm{~b} \\
\pm 0.17\end{array}$ & $\begin{array}{c}12.61 \mathrm{c} \\
\pm 0.19\end{array}$ \\
\hline $\begin{array}{c}\text { After } \\
120 \text { days }\end{array}$ & $\begin{array}{c}136.63 a \\
\pm 0.25\end{array}$ & $\begin{array}{c}109.30 \mathrm{~b} \\
\pm 0.25\end{array}$ & $\begin{array}{c}92.40 \quad \text { с } \\
\pm 0.36\end{array}$ & $\begin{array}{c}58.68 \mathrm{~d} \\
\pm 0.39\end{array}$ & $\begin{array}{c}17.29 \quad \mathrm{a} \\
\pm 0.17\end{array}$ & $\begin{array}{c}16.7 \mathrm{ab} \\
\pm 0.19\end{array}$ & $\begin{array}{c}16.20 \mathrm{~b} \\
\pm 0.19\end{array}$ & $\begin{array}{c}14.83 \text { c } \\
\pm 0.27\end{array}$ \\
\hline $\begin{array}{c}\text { After } \\
150 \text { days }\end{array}$ & $\begin{array}{c}182.19 \mathrm{a} \\
\pm 0.47\end{array}$ & $\begin{array}{c}144.8 \mathrm{~b} \\
\pm 0.40\end{array}$ & $\begin{array}{c}120.79 \quad \text { с } \\
\pm 0.47\end{array}$ & $\begin{array}{c}74.70 \quad \mathrm{~d} \\
\pm 0.32\end{array}$ & $\begin{array}{c}19.77 \quad \mathrm{a} \\
\pm 0.23\end{array}$ & $\begin{array}{c}19.1 \mathrm{ab} \\
\pm 0.22\end{array}$ & $\begin{array}{c}18.79 \mathrm{~b} \\
\pm 0.26\end{array}$ & $\begin{array}{c}17.38 \mathrm{c} \\
\pm 0.18\end{array}$ \\
\hline $\begin{array}{c}\text { After } \\
180 \text { days }\end{array}$ & $\begin{array}{c}231.86 a \\
\pm 0.58\end{array}$ & $\begin{array}{c}182.8 \mathrm{~b} \\
\pm 0.37\end{array}$ & $\begin{array}{c}151.19 \text { с } \\
\pm 0.44\end{array}$ & $\begin{array}{c}91.65 \mathrm{~d} \\
\pm 0.47\end{array}$ & $\begin{array}{c}22.12 \text { a } \\
\pm 0.45\end{array}$ & $\begin{array}{c}21.48 \mathrm{~b} \\
\pm 0.30\end{array}$ & $\begin{array}{c}92.4 \mathrm{~b} \\
\pm 0.35\end{array}$ & $\begin{array}{c}20.32 \text { c } \\
\pm 0.42\end{array}$ \\
\hline
\end{tabular}

Values are means \pm S.E of two replicates

Means in the same raw having the same superscript are not significantly different $(\mathrm{p}<0.05)$

On the other hand the results of average of body length of $M$. cephalus through intervals which are represented in Table (2), was $6.5 \pm 0.05$ for all treatments. That indicates that all M.cephalus fingerling had the same length when they were stocked at the start of experiment.

As represented in Table (2) results revealed that the stocking density of grey mullet effects on its length from the first interval (after 30 days of the experiment starting) to the end of the experiment. The averages of body length of grey mullet at the first interval were $9.42 \pm 0.10,9.08 \pm 0.11,9.02 \pm 0.11$ and $8.50 \pm 0.15 \mathrm{~cm} . /$ fish for $\mathrm{T}_{1}, \mathrm{~T}_{2}, \mathrm{~T}_{3}$ and $\mathrm{T}_{4}$ respectively. Result revealed that the value of $T_{1}$ was significantly $(P<0.05)$ higher than those of $T_{2} T_{3}$ and $T_{4}$, but, $T_{2}$ and $T_{3}$ were significantly higher than that of $T_{4}$. The same trend was observed at 
the final interval where the average values of grey mullet length were $22.12 \pm$ 0.45, $21.48 \pm 0.30,21.28 \pm 0.36$ and $20.32 \pm 0.42 \mathrm{~cm} /$ fish for $\mathrm{T}_{1}, \mathrm{~T}_{2}, \mathrm{~T}_{3}$ and $\mathrm{T}_{4}$ respectively. These result are in agreement with those reported by (Esaa, 1996) he found that the mean individual growth rate and body length of M.cephalus were highest for the lower stocking density and lowest for the higher stocking density.

\section{The Specific Growth Rate (SGR \%):}

The effects of stocking density on SGR (\%) are represented in Table (3). The results revealed a significant $(\mathrm{P}<0.05)$ difference among treatments. They were at the first Interval (after30 days) 3.19, 2.69, 2.40 and 1.57 for $T_{1}, T_{2}, T_{3}$ and $\mathrm{T}_{4}$ respectively. The result of $\mathrm{SGR} \% \mathrm{kept}$ the same trend through all experimental intervals. They were $0.80,0.78,0.75$ and $0.69 \%$ at the final interval (after 180 days) for $\mathrm{T}_{1}, \mathrm{~T}_{2}, \mathrm{~T}_{3}$ and $\mathrm{T}_{4}$ respectively.

Table (3) Average of growth parameters of grey mullet (M. cephalus) during experimental period (180 days).

\begin{tabular}{|c|c|c|c|c|}
\hline ITEMS & T1 & $\mathbf{T} 2$ & T3 & T4 \\
\hline $\begin{array}{l}\text { SGR\% of first interval (after } 30 \\
\text { days): }\end{array}$ & $\begin{array}{l}3.19 \quad \mathrm{a} \\
\pm 0.01\end{array}$ & $\begin{array}{l}2.69 \quad \mathrm{~b} \\
\pm 0.02\end{array}$ & $\begin{array}{l}2.40 \quad \text { c } \\
\pm 0.01\end{array}$ & $\begin{array}{l}1.57 \quad \mathrm{~d} \\
\pm 0.01\end{array}$ \\
\hline $\begin{array}{l}\text { SGR\% of final interval (after } 180 \\
\text { days): }\end{array}$ & $\begin{array}{l}0.80 \quad \mathrm{a} \\
\pm 0.002\end{array}$ & $\begin{array}{c}0.78 \quad b \\
\pm 0.007\end{array}$ & $\begin{array}{l}0.75 \quad \text { с } \\
\pm 0.005\end{array}$ & $\begin{array}{l}0.69 \quad \mathrm{~d} \\
\pm 0.006\end{array}$ \\
\hline $\begin{array}{l}\text { RGR\% of first interval (after } 30 \\
\text { days): }\end{array}$ & $\begin{array}{r}160.09 \quad \mathrm{a} \\
\pm 0.41\end{array}$ & $\begin{array}{c}124.0 \quad \mathrm{~b} \\
\pm 1.03\end{array}$ & $\begin{array}{c}105.21 \text { c } \\
\pm 0.44\end{array}$ & $\begin{array}{l}59.95 \mathrm{~d} \\
\pm 0.29\end{array}$ \\
\hline $\begin{array}{l}\text { RGR\% of final interval (after } 180 \\
\text { days): }\end{array}$ & $\begin{array}{l}27.27 \quad \text { a } \\
\pm 0.06\end{array}$ & $\begin{array}{c}26.28 \quad \text { b } \\
\pm 0.25\end{array}$ & $\begin{array}{l}25.19 \quad \mathrm{C} \\
\pm 0.17\end{array}$ & $\begin{array}{l}22.69 \mathrm{~d} \\
\pm 0.22\end{array}$ \\
\hline $\begin{array}{l}\text { The average of Condition factor } \\
\text { (K) through the experimental } \\
\text { period: }\end{array}$ & $\begin{array}{l}3.16 \quad \text { a } \\
\pm 0.67\end{array}$ & $\begin{array}{l}2.39 \quad b \\
\pm 0.07\end{array}$ & $\begin{array}{l}2.72 \quad b \\
\pm 0.08\end{array}$ & $\begin{array}{l}2.46 \quad \mathrm{c} \\
\pm 0.09\end{array}$ \\
\hline $\begin{array}{l}\text { The average of total weight gain } \\
\text { through the experimental period } \\
\text { (g / fish / interval): }\end{array}$ & $\begin{array}{r}36.63 \quad \mathrm{a} \\
\pm 1.22\end{array}$ & $\begin{array}{l}28.45 \quad b \\
\pm 0.65\end{array}$ & $\begin{array}{l}23.18 \quad \mathrm{C} \\
\pm 0.05\end{array}$ & $\begin{array}{l}13.26 \mathrm{~d} \\
\pm 0.28\end{array}$ \\
\hline $\begin{array}{l}\text { The average of Daily weight Gain } \\
\text { (DWG) through the experimental } \\
\text { period (g/fish): }\end{array}$ & $\begin{array}{l}1.22 \quad \mathrm{a} \\
\pm 0.03\end{array}$ & $\begin{array}{l}0.95 \quad b \\
\pm 0.22\end{array}$ & $\begin{array}{l}0.77 \quad \mathrm{c} \\
\pm 0.2\end{array}$ & $\begin{array}{l}0.44 \mathrm{~d} \\
\pm 0.01\end{array}$ \\
\hline
\end{tabular}


Data indicates that the lowest density of M.cephalus showed the highest SGR (\%) records compare with those of the highest densities. These results are in agreement with those recorded by (El-Sayed, 2002), who reported that fish survival percentage, weight gain and specific growth rate (SGR \%) of M.cephalus negatively correlated with stocking density.

The Relative Growth Rate (RGR \%):

The results of RGR (\%) of $M$. cephalus in the present study are illustrated in Table (3). Values of RGR (\%) at the first interval (after 30 days) were 160.9, 124.0, 105.21 and 59.9569 for $T_{1}, T_{2}, T_{3}$ and $T_{4}$ respectively. They had a significant $(\mathrm{P}<0.05)$ difference among treatments. At the final interval (after 180 days), the values of RGR\% were 27.27, 26.28, 25.19 and 22.69 for $\mathrm{T}_{1}$, $\mathrm{T}_{2}, \mathrm{~T}_{3}$ and $\mathrm{T}_{4}$ respectively with significant difference $(\mathrm{P}<0.05$. These results are in agreement with those of (Scorvo, et al; 1995) and (Sampaio, et al; 2001), who reported that grey mullet M.cephalus reared in monoculture and in lower density, had greater growth and weight gain.

\section{Condition Factor (K):}

Average of condition factor (K) values of M.cephalus as represented in Table (3) increased significantly $(\mathrm{p}<0.05)$ with decreasing the stocking density. Results of average condition factor $(\mathrm{K})$ per experimental intervals were 3.16, 2.93, 2.72 and 2.64 for $T_{1}, T_{2}, T_{3}$ and $T_{4}$ respectively. It can be observed that $T_{1}$ had the highest value of condition factor $(K)$ compared with the others values of $T_{2}, T_{3}$ and $T_{4}$ $(p<0.05)$. But the values of $T_{2}$ and $T_{3}$ had a higher value than $T_{4}(p<0.05)$. The results showed that the average of $(\mathrm{K})$ values of M.cephalus increased significantly $(\mathrm{p}<0.05)$ with increasing the stocking density compared with lower stocking density.

\section{Total Weight Gain and Daily Weight Gain (DWG):-}

The average of total weight gain through the experimental period (g/fish/ interval $\}$ and the average of daily weight gain (DWG) of M.cephalus through the experimental period (g/fish) were recorded in Table (3). The results of average of body weight gain per the interval (30 days) were 36.63, 28.45, and 23.18 and $13.26 \mathrm{~g} /$ fish for $\mathrm{T}_{1}, \mathrm{~T}_{2}, \mathrm{~T}_{3}$ and $\mathrm{T}_{4}$ respectively. The differences among groups were significant $(\mathrm{p}<0.05)$.

Daily weight gain results of $M$. cephalus in gram /fish /day, were 1.22, 0.95, 0.77 and $0.44 \mathrm{~g}$ /fish for $\mathrm{T}_{1}, \mathrm{~T}_{2}, \mathrm{~T}_{3}$ and $\mathrm{T}_{4}$ respectively, through the experimental period (180 days), and the differences among groups were significantly $(\mathrm{p}<0.05)$. Results indicated that DWG of M.cephalus decreased as the stocking density increased .These are in agreement with the results of (Zied, et al; 2005), who found that harvesting body weight, total gain, daily weight gain and specific growth rate of $M$. cephalus and Oreochromis niloticus were affected by stocking density rates.

\section{Survival Rate (\%):}

Results represented in Table (4) illustrated the effect of different stocking densities of M.cephalus on its survival rates, final biomass, weight gain 
and final total production per feddan ( $0.42 \mathrm{ha})$. The results of survival rates were $96 \%, 92.5 \%, 88 \%$ and $81.5 \%$ for $\mathrm{T}_{1}, \mathrm{~T}_{2}, \mathrm{~T}_{3}$ and $\mathrm{T}_{4}$ respectively. These results indicated that stocking density of M.cephalus had affect on their survival rates. Also, the results are in accordance with those of (Abdel-Ghany, et al; 1995), who reported that, the survival of the grey mullet $M$. cephalus exceeded $97 \%$ and it did not appear to be affected by quantity or quality of food. Also, they in agreement with findings of (El-Sayed; 2002, and Eid, 2006), who found that fish survival percentage, weight gain and specific growth rate (SGR \%) negatively correlated with stocking density.

Table (4) Final body weight, number of livability, survival \%, final weight gain, costumed fertilizers and total production per feddan (0.42 ha) of M. cephalus cultured at different stocking density in monoculture system for 180 days.

\begin{tabular}{|l|c|c|c|c|}
\hline \multicolumn{1}{|c|}{ ITEMS } & T1 & T2 & T3 & T4 \\
\hline Average area of pond (ha.): & 0.1 & 0.1 & 0.1 & 0.1 \\
\hline Culture period (days): & 180 & 180 & 180 & 180 \\
\hline $\begin{array}{l}\text { No. of stocked fish at start of experiment. } \\
\text { (Fish/feddan): }\end{array}$ & 1050 & 1400 & 2100 & 4200 \\
\hline Average initial body weight (g/fish): & 12.10 & 12.10 & 12.10 & 12.10 \\
\hline Initial biomass. (Kg/feddan): & 12.71 & 16.94 & 25.41 & 50.82 \\
\hline $\begin{array}{l}\text { Final biomass (total production) } \\
\text { (Kg/feddan): }\end{array}$ & 233.7 & 236.8 & 273.0 & 313.9 \\
\hline No., of fish mortality (Fish/feddan) & 42 & 105 & 294 & 775 \\
\hline No., of survival fish (Fish/feddan) & 1008 & 1295 & 1806 & 3425 \\
\hline Survival rate (\%) & 96 & 92.5 & 88 & 81.5 \\
\hline Average final body weight (g/fish) & 231.86 & 182.82 & 151.19 & 91.65 \\
\hline Final body weight gain (g/fish & 219.76 & 170.72 & 139.09 & 79.55 \\
\hline Average initial body length (cm) & 6.51 & 6.51 & 6.51 & 6.51 \\
\hline Average final body length (cm) & 22.12 & 21.48 & 21.28 & 20.32 \\
\hline Total weight gain/ feddan ( kg/feddan) & 221.0 & 220.3 & 247.6 & 263.1 \\
\hline Costumed chicken manure (m3/feddan) & 2.5 & 2.5 & 2.5 & 2.5 \\
\hline Costumed chicken manure (Kg/feddan) & 360 & 360 & 360 & 360 \\
\hline Costumed chicken manure (Kg/feddan) & 120 & 120 & 120 & 120 \\
\hline
\end{tabular}

\section{Total Production:}

As represented in Table (4), the average of initial biomass of M.cephalus per feddan (0.42ha) was 6.41, 8.54, 12.81 and $26.62 \mathrm{Kg} /$ fedaan for $\mathrm{T}_{1}, \mathrm{~T}_{2}, \mathrm{~T}_{3}$ and $\mathrm{T}_{4}$ respectively. Final biomass values of M.cephalus (total production) were 233.7, 236.8, 273.0 and $313.9 \mathrm{Kg} /$ feddan (0.42ha) for $\mathrm{T}_{1}, \mathrm{~T}_{2}, \mathrm{~T}_{3}$ and $\mathrm{T}_{4}$ respectively. These results indicate that decreasing of M.cephalus stocking density decreased its final biomass.

On the other hand, the final body weight per fish was the biggest for $T_{1}$ (231.86 g/fish), comparing with the other treatments which was 182.82, 151.19 and $91.65 \mathrm{~g} /$ fish for $\mathrm{T}_{2}, \mathrm{~T}_{3}$ and $\mathrm{T}_{4}$ respectively. So, the price of big fish is higher than the small one. Theses results are in agreement with (Eid, 2006, and Bakeer, 2006). 


\section{Economical evaluation:-}

Results in Table (5) indicate that the highest net return was 1860.38 L.E per feddan (0.42 ha) for $\mathrm{T}_{1}$ followed by $\mathrm{T}_{2}$ that was $1247.78 \mathrm{~L} . \mathrm{E}$ and 1074.38 L.E for $T_{3}$ while the $T_{4}$ had negative net return which was (-175.62 L.E).

Table (5): The effect of different stocking densities on economic efficiency of growing grey mullet calculated in monoculture system ponds, area of feddan (0.42ha).

\begin{tabular}{|l|c|c|c|c|}
\hline \multicolumn{1}{|c|}{ ITEMS } & T1 & T2 & T3 & T4 \\
\cline { 1 - 4 } Operating costs: & & & & \\
\hline 1- Variable costs: & 525.00 & 700.00 & 1050 & 2100.00 \\
\hline a- Fingerlings & & & & \\
\hline b- Fertilizers & 150.00 & 150.00 & 150.00 & 150.00 \\
\hline I-Chicken manure : & 173.00 & 173.00 & 173.00 & 173.00 \\
\hline II-Super phosphate & 54.00 & 54.00 & 54.00 & 54.00 \\
\hline III- Urea : & 50.00 & 50.00 & 50.00 & 50.00 \\
\hline c- Transportation: & 300.00 & 300.00 & 300.00 & 300.00 \\
\hline d- Labor & 1252.00 & 1427.00 & 1777 & 2827 \\
\hline Total variable costs : & & & & \\
\hline 2- Fixed costs: & 200.00 & 200.00 & 200.00 & 200.00 \\
\hline a-Depreciation (material and other) & 100.00 & 100.00 & 100.00 & 100.00 \\
\hline b- Taxes & 93.12 & 103.62 & 124.62 & 187.62 \\
\hline c- interest* & 393.12 & 403.62 & 424.62 & 487.62 \\
\hline Total fixed cost : & 1645.12 & 1830.62 & 2201.62 & 3314.62 \\
\hline 3- Total operating costs (1 + 2): & 3505.50 & 3078.40 & 3276.0 & 3139.00 \\
\hline 4- Return** (fish sales in L.E /fed.) & 1860.38 & 1247.78 & 1074.38 & -175.62 \\
\hline 5-Net return in L.E / fed. (4-3): & 113.08 & 68.16 & 48.80 & ---- \\
\hline Rate of return \% (5/3) x100: & & & & \\
\hline
\end{tabular}

$* 12 \%$ of total operating costs $\times(180 / 360$ days).

** Return $=$ the total production $\mathrm{x}$ the price of one $\mathrm{kg}$ of fish per group.

- $\quad$ The economical evaluation of results was carried out according to market prices in 2006 in L.E

- $\quad$ The price of one fingerling was 0.5 L.E

- $\quad$ The price of $1 \mathrm{~m}^{3}$ of chicken manure was $50.00 \mathrm{~L} . \mathrm{E}$

- $\quad$ The price of 1 ton of super phosphate was 480.00 L.E and of Urea was 450.00 L.E

- $\quad$ Labor: 2 workers for a fed. (Each had salary 200 L.E monthly).

- $\quad$ The price of one kg of fish for first group $\left(T_{1}\right)$ was15 LE, for second group $\left(T_{2}\right)$ was $13 \mathrm{LE}$, for third group $\left(T_{3}\right)$ was $12 \mathrm{LE}$, and for fourth group $\left(T_{4}\right)$ was $10 \mathrm{LE}$.

Transportation was 50 L.E approximately.

To measure the profitability for each stocking density, the rate of return was calculated. As shown in Table (5), $\mathrm{T}_{1}$ had the highest rate of return (113.08 $\%$ ) followed by $\mathrm{T}_{2}(68.16 \%)$ and $\mathrm{T}_{3}(48.80 \%)$, while $\mathrm{T}_{4}$ was avoided from the calculating.

Conducting sensitivity analysis for the four treatments was calculated with the following assumptions (Barrania et al; 1996):

1) Increasing costs by $10 \%$ and $15 \%$.

2) Decreasing in fish prices by $10 \%$.

3) Decreasing in fish production by 10 and $20 \%$.

So, Tables $\left(6,7\right.$, and 8 ) showed that $T_{1}, T_{2}$ and $T_{3}$ maintained positive net return. This indicated reducing of the risk to farmers in the events of unexpected fall in market price and production or the increase of costs. 
Table (6): Represent sensitivity analysis for treatment $\left(\mathrm{T}_{1}\right)$

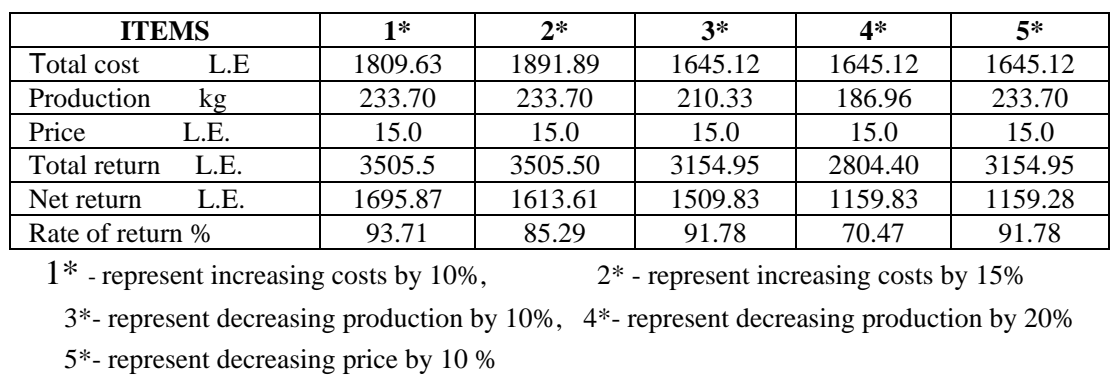

Table (7): Represent sensitivity analysis for treatment $\left(\mathrm{T}_{2}\right)$

\begin{tabular}{|lc|c|c|c|c|c|}
\hline \multicolumn{2}{|c|}{ ITEMS } & $\mathbf{1}$ & $\mathbf{2}$ & $\mathbf{3}$ & $\mathbf{4}$ & $\mathbf{5}$ \\
\hline Total costs & L.E & 2013.68 & 2105.21 & 1830.62 & 1830.62 & 1830.62 \\
\hline Production & KG & 236.80 & 236.80 & 213.12 & 189.44 & 236.80 \\
\hline Price of 1 kg & L.E & 13.00 & 13.00 & 13.00 & 13.00 & 11.70 \\
\hline Total return & L.E & 3078.40 & 3078.40 & 2770.56 & 2462.72 & 2770.56 \\
\hline Net return & L.E & 1064.72 & 973.19 & 939.94 & 632.10 & 939.94 \\
\hline \multicolumn{2}{|l|}{ Rate of return \% } & 52.87 & 46.23 & 51.35 & 34.53 & 51.35 \\
\hline
\end{tabular}

Table (8): Represent sensitivity analysis for treatment $\left(\mathrm{T}_{3}\right)$

\begin{tabular}{|ll|c|c|c|c|c|}
\hline \multicolumn{2}{|c|}{ ITEMS } & $\mathbf{1}$ & $\mathbf{2}$ & $\mathbf{3}$ & $\mathbf{4}$ & $\mathbf{5}$ \\
\hline Total costs & L.E & 2421.78 & 2531.86 & 2201.62 & 2201.62 & 2201.62 \\
\hline Production & KG & 273.00 & 273.00 & 245.70 & 218.40 & 273.00 \\
\hline Price of $1 \mathrm{~kg}$ & L.E & 12.00 & 12.00 & 12.00 & 12.00 & 10.80 \\
\hline Total return & L.E & 3276.00 & 3276.00 & 2948.40 & 2620.8 & 2948.40 \\
\hline Net return & L.E & 854.22 & 744.14 & 746.78 & 419.18 & 746.78 \\
\hline Rate of return \% & & 35.27 & 29.39 & 33.92 & 19.04 & 33.92 \\
\hline
\end{tabular}

\section{CONCLUSION}

According to obtained results, economic evaluation and sensitivity analysis, it could be concluded that the first treatment $\left(T_{1}\right)$ that received the lowest stocking density at the rate of 1050 Mugil cephalus fingerlings per feddan (0.42 ha.), without any supplementary food, and cultured for 180 days in monoculture system, had the highest net return and rate of return followed by $\mathrm{T}_{2}$ and $\mathrm{T}_{3}$, which can reduce risk for the farmer in the event of unexpected fall in market price or production or increasing of costs.

\section{REFERANCES}

Abdel-Gawad, A. S; (2003). Effect of stocking different ratios of Nile tilapia and grey mullet in polyculture ponds: on growth performance and total yield. J. Egypt .Acad. Soc. Environ Develop., (B-Aquaculture), 4, (2):97-118.

Abdel-Ghany, A.E.; Eid, A.M; Hermis, I.H. and Ibrahim, H.I. (1995). Digestibility of feed and growth response of grey mullet (Mugil 
cephalus L.) fed on natural food and /or formulated diet in fresh water ponds. Egypt. J. Agric. Res., 73(3): 841-989.

Abdel-Hakim, N. F; Mohammed, S L. Mohammed, N.B. and Abdel- Rahman, A.K. (2006). Effect of different feeding levels on growth performance and pond productivity of Nile tilapia (Oreochromis niloticus),grey mullet (Mugil cephalus) and common carp (Cyprinus carpio) reared in polyculture system. Egyptian J. of Aquatic Biology and Fishries, 10(4).

Abd-El-Tawab, A.M. and Yones, A.A. (2001). Environmental and nutritional studies on rearing of grey mullet Mugil cephalus in Fayoum fish farm. Egyptian J. Nutrition and Feeds, 4: 719-730.

Abdel-Tawwab, M; Eid, A.M; Abdel-Ghany, A.E. and El-Marakby, H.I. (2005). The assessment of water quality and primary productivity in earthen ponds stocked with stripped mullet (Mugil cephalus) and subjected to different feeding regimes. Turkish Journal of Fisheries and Aquatic Sciences, 5(1): 1-10.

APHA, (American Public Health Association), (1985): Standard Methods for the examination of water and wastewater.

Artiles, M. A.; Reyes, R.; Tizol, R.(2001). Mixed cultivation of mullet (Mugil liza) and white shrimp (Litopenaeus schmitti)in ponds. Bol. Cent. Invest. Biol. Maracaibo, 35(3): 325-338.

Bakeer, M.N. (2006). Performance of grey mullet (Mugil cephalus L.) reared in monoculture in the new desert areas. Journal of Arabian Aquaculture Society, December, 1(2): 44-56.

Barrania, A. A; Essa, M. A; El-Gamal, A. A; Othman, M. F; Sadek, S. S. (1996). Scientific and applied basics for hatching and rearing of Fish and crustacean. Book in Arabic, First Edition, Second partition; pp.387-441.

Blanco, S; Romo, S; Villena, M.J; Martinez, S. (2003). Fish communities and food web interaction in some shallow Mediterranean lakes. Hudrobiologia, 506-509: 473-480.

Boyd, C.E. (1992). Water quality in warm water fish ponds. Alabama Agric. Experiment Station, Auburn Univ., Alabama. 
Cardona, L.; Torras, X; Gisbert, E; and Castella, F, (1996). The effect of stripped grey mullet (Mugil cephalus, L.) on fresh water ecosystems. Israeli- Journal of Aquaculture, 48 (4):179-185.

Duncan, D.B. (1955). Multiple range and multiple "F" tests. Biometrics, 11:142.

Eid, A.M. (2006). Effect of stocking density on growth performance and production of grey mullet (Mugil cephalus). Egyptian Journal of Aqua cultural Research, Special issue, The First Scientific Conference on Modern Attitudes in Aquaculture; 84(1):51-59.

El- Sayed, A. M., (2002). Effect of stocking and feeding levels on growth and feed efficiency of Nile tilapia (Oreochromis niloticus L.) fry. Aquaculture- Research (Aquacult -Res.), 33 (8): 621 - 626.

Essa, M. A.; El- Sherif, Z. M; Abdel - Ezz and Abdel- Moati, A. R. (1989). Effect of water quality, food viability and crowding on rearing condition and growth parameters of some economical fish species grown under poly culture system. Bull. Nati. Ins., Oceanogr. Fish- Egypt, 15 (1): 125 $-134$.

Essa, M.A. (1996). The effect of fish density and feeding frequency on both (Oreochromis niloticus and Mugil cephalus) fish reared as mixed culture in floating cages. Bull. - Batt. Oceanogr.-Fish,- Egypt, 22:181 - 197.

Gisbert, E; Cardona, L. and Catella, E. (1995).Competition between mullet fry. Journal of fish Biology, 47(3): 414-420.

Jana, S.N; Garg, S.K; Patra, B.C. (2004): Effect of periphyton on growth performance of grey mullet, Mugil cephalus (Linn), in inland saline groundwater ponds. Journal of Applied Icthology, 20(2):110-117.

Magouz, F.I; Mahmoud, S. A. and Abo-Omar, Z.M.B.( 1999). Effect of chemical fertilizers on productivity of fish in polyculture earthen pond. Egyptian Journal of Nutrition and Feeds, 2 (Special issue): pp743-751.

Oren, O.H. (1981). Aquaculture of mullet. International Biological Program No.26.Cambridge; Cambridge University press, London, 450 pp. ISBN: 0-521-22926-X. 
Sampaio, L.A; Ferreira, A.H. and Tesser, M.B. (2001). Effect of stocking density on laboratory rearing of mullet fingerlings, Mugil platanus (Gunther, 1880).Acta, Scientiarum, 23(2):471-475.

SAS (1985): SAS/STAT Guide for personal computers. Version 6 edition SAS Institute Inc., Cary, North Carolina. USA.

Scorvo, Filho, J.D; Da, S. Ayroza, L.M. Colherinhas, N. P.F. and De.Almeida, Dias, E.R. (1995). Effect of density on the growth of striped mullet (Mugil cephalus) reared in mono and polyculture with common carp (Cyprinus carpio), in Vale de Ribeira region. J. Bol. Inst. Resca. Sao. Paulo, 22(2): 85-93.

Shang, Yung C. (1981). Aquaculture Economics: Basic Concepts and Methods of Analysis. Westview Press. Boulder. Colorado.

Smith, M.s.; and Swart,J.J. (1998). Flathead mullet (Mugil cephalus) as potential aquaculture species in Western Cape; African Fishes and Fisheries, Diversity and Utilization, Poissons et Peches, Africans Diversite et Utilization Coetzee, L; (ed ) : Gon; J. (ed O; Kulongoski, C;(ed). Graham's town, South Africa, FISA; PARADI, 241pp.

Soliman, A. K; El-Hobeety, A. A. A; Essa, M. A. R; Kosba, M. A; Kariony, I. A.(2000). Effect of introducing ducks into fish ponds on water quality, natural productivity and fish production together with economic evaluation of the integrated and non-integrated systems. Aquaculture International, 8 (4): 315-326.

Swart, J.j.; Smith, M.s.; and King, P. R. (2001). The effect of artificial feed and probiotics on the growth of mullet (Mugil cephalus and Liza richadsoni.) Aquaculture. Book of Abstracts, 143. J.M.Paker, Coliseum, Louisiana State University, Baton, Rouge, La 70803-USA. World Aquaculture Society, 629pp.

Torras, x.; Cardona, L. and Gisbert, E. (2000). Cascading effects of the flathead grey mullet Mugil cephalus in fresh water eutrophic micro cosmos, Hydrobiology, 429 (1/3) :49-57.

Zied, R.M.A.; El-Maksoud, A.M.S.A. and Ali, A.A.A. (2005). Effect of stocking density rates of Nile tilapia (Oreochromis niloticus L.) and grey mullet (Mugil cephalus L.) on their performance in poly culture earthen ponds. Annals of Agriculture Science, Moshtohor, 43(3):1057-1066. 